\title{
EFEKTIVITAS SISTEM INFORMASI DALAM MENINGKATKAN KINERJA KARYAWAN SEBAGAI LAPORAN PERTANGGUNGJAWABAN
}

\author{
Kristina Anindita ${ }^{*}$, Maliana Puspa ${ }^{2}$, Wilhelmina Kosnan ${ }^{3}$ \\ 1,2,3 Jurusan Magister Sains, Ekonomi dan Bisnis, Universitas Jenderal Soedirman, Jl. HR. Boenyamin No. \\ 708, Purwokerto 531222, Jawa Tengah, Indonesia \\ Email: aninditakristina@gmail.com
}

\begin{abstract}
Abstraksi
Informasi menjadi faktor penting bagi perusahaan karena merupakan salah satu sumber daya yang dapat diolah untuk menunjang kegiatan bisnis ditengah-tengah persaingan yang semakin ketat. Peran sistem informasi manajemen adalah untuk mengelola data, pengorganisasian, dan mengambil informasi yang membantu organisasi untuk menyediakan layanan yang lebih cepat, lebih akurat dan lebih mudah, yang mempengaruhi juga pada tingkat kinerja. Pemanfaatan sistem informasi secara efektif dapat meningkatkan kinerja karyawan. Jenis penelitian ini adalah kualitatif dengan pendekatan studi kasus di ELTI Gramedia Purwokerto dengan melakukan wawancara mendalam kepada 6 karyawannya. Kualitas sistem informasi dan kemudahan dalam mengoperasionalkan sistem membuat karyawan bekerja lebih produktift, efektif dan efisien.
\end{abstract}

Kata Kunci: Sistem Informasi Manajemen, Kualitas Informasi, Kinerja Karyawan.

Abstract

Information is an important factor for the company because it is one resource that can be processed to support business activities amid increasingly fierce competition. The role is a management information system to manage data, organizing, and retrieving information that helps organizations to provide services faster, more accurately and more easily, which affects also the performance level. Use of information systems can effectively improve the performance of employees. The research is a qualitative case study approach in Purwokerto Gramedia ELTI by conducting in-depth interviews to 6 employees. The quality of information systems and services to operationalize the system makes employees work more produktift, effective and efficient.

Keyword : Management Information System, Information Quality, Employee Performance

\section{Pendahuluan}

Sebuah informasi menjadi faktor yang penting bagi perusahaan karena merupakan salah satu sumber daya yang dapat diolah untuk menunjang kegiatan bisnis ditengah-tengah persaingan yang semakin ketat.Peran teknologi dan sistem informasi menjadi sangat penting di dunia bisnis dan tidak akan pernah dapat dipisahkan. Teknologi informasi mengubah cara kerja manusia atau organisasi baik dalam cara berkomunikasi, cara mengkoordinasi, cara memproduksi serta pemanfaatan teknologi lainnya didalam berbagai sistem bisnis dan organisasi.

Sistem informasi adalah suatu kumpulan dari komponen-komponen dalam suatu perusahaan atau organisasi yang berhubungan dengan proses penciptaan dan pengaliran informasi atau merupakan 
Efektivitas Sistem Informasi Dalam Meningkatkan Kinerja...

salah satu komponen dalam perusahaan (Ali, 2010). Sistem informasi dapat juga dikatakan sebagai totalitas terpadu yang terdiri dari prosedur, tenaga pengolah (brainwaare), perangkat lunak (software), perangkat keras (hardware), pangkalan data (database) perangkat telekomunikasi (telecommunication) yang saling ketergantungan dan saling menentukan dalam rangka menyediakan informasi untuk mendukung proses pengambilan keputusan.

Perkembangan teknologi informasi telah mempengaruhi sistem pengolahan data serta sistem informasi dalam pelaporan keuangan perusahaan. Berhubungan dengan metode analisis laporan keuangan dan penerapan teknologi informasi dalam berbagai analisis keuangan, hal ini merupakan suatu tolok ukur bagi kemajuan pelaporan keuangan.Terutamaterhadap upaya setiap institusi bisnis, untuk menyeimbangkan perkembangan teknologi informasi yang selaras dengan pekembangan analisis pelaporan keuangan.Untuk dapat melakukan pengolahan data keuangansecara efektif dan efisien maka dibutuhkan suatusistem informasi terintegrasi yang dapat diandalkan, cepat dan akurat sehingga suatu sistem dapat diintegrasikan secara menyeluruh dan mampu memberikan informasi yang handal dan relevan (Nugraha dan Astuti, 2013).

Akhir-akhir ini, hubungan antara sistem informasi dan kinerja menjadi sorotan penelitian. Pembangunan sistem informasi berbasis komputer, mengalihkan seluruh kegiatan tradisional atau manual kedalam sistem komputerisasi. Sudah banyak perusahaan atau organisasi yang memanfaatkan komputer dan sistem informasi untuk berbagai keperluan. Teknologi membantu untuk mengurangi biaya manajerial, biaya manusia, dan membuat pekerjaan lebih akurat serta lebih cepat. Peran sistem informasi manajemen adalah untuk mengelola data, pengorganisasian, dan mengambil informasi yang membantu organisasi untuk menyediakan layanan yang lebih cepat, lebih akurat dan lebih mudah, yang mempengaruhi juga pada tingkat kinerja (Gharaibeh dan Malkawi, 2013).

Sistem informasi manajemen memungkinkan karyawan untuk melakukan pekerjaan mereka dengan tingkat ketepatan yang tepat dari informasi yang diberikan oleh sistem (Al Meetany, 2004). Sedangkan Fisher dan Kenny (2000) mengemukakan bahwa organisasi menerapkan sistem informasi ke dalam kegiatan operasional mereka sehingga dapat meningkatkan daya saing, memfasilitasi pertumbuhan bisnis dan meraih kesuksesan. Gagasan untuk menggunakan komputer sebagai sistem informasi manajemen (SIM), merupakan suatu terobosan besar, karena menyadari bahwa para manajer memerlukan informasi untuk pemecahan masalah. SIM yang berbasis komputer telah menciptakan kemungkinan untuk mengatasi keterbatasan fisik pada perusahaan untuk melakukan berbagai pekerjaan. Peningkatan efisiensi dan efektifitas kinerja secara otomatis akan meningkatkan kinerja karyawan.

Memiliki kompetensi di bidang bahasa asingsudah menjadi kebutuhan setiap orang dalam rangka mengembangkan potensi dan eksistensi diri. Bahasa Inggris merupakan salah satu bahasa asing yang dibutuhkan dalam dunia pendidikan, kerja bahkan dunia bisnis. Hal ini yang mendorong masyarakat, termasuk di wilayah Kabupaten Banyumas untuk meningkatkan kompetensi dalam penguasaan bahasa 
Inggris di lembaga-lembaga pendidikan non formal. ELTI Gramedia Purwokerto hadir sebagai salah satu lembaga pendidikan bahasa Inggris yang mampu memenuhi kebutuhan dan keinginan masyarakat dalam penguasaan bahasa Inggris. Walaupun bukan menjadi lembaga pendidikan bahasa inggris yang pertama di Purwokerto, namun ELTI mampu bersaing dengan menonjolkan keunggulan kompetitif yang dimilikinya. Tradisi pelayanan yang sangat kuat di ranah pendidikan, terutama pendidikan bahasa Inggris ditambah dengan fasilitas pendukung dan media mengajar yang memadai, telah menjadikan ELTI Gramedia Purwokerto sebagai lembaga pendidikan bahasa Inggris yang berkualitas bagi masyarakat mulai dari anak-anak sampai dengan para professional di berbagai bidang. Program - program yang ditawarkan ELTI sangat lengkap dan mampu memenuhi apa yang menjadi keinginan dan kebutuhan konsumen. Harga yang ditawarkan pun kompetitif dan mampu bersaing dengan lembaga pendidikan bahasa Inggris lain di Purwokerto. Menempatkan kelas tidak hanya dari sisi kemampuan tetapi juga didasarkan pada sisi psikologis calon siswa menjadi keunikan dari ELTI Gramedia. Metode ini membuat proses belajar mengajar dan suasana di dalam kelas menjadi lebih nyaman.

Perkembangan ELTI semakin pesat ditunjukkan dengan pangsa pasar yang semakin luas hingga Kabupaten Purbalingga, Cilacap, Banjarnegara dan Kebumen. Lembaga ini menerapkan sistem informasi di dalam kegiatan operasional perusahaan, namun belum optimal. Karyawan masih melakukan beberapa pekerjaan secara manual karena sistem yang belum sempurna. Berdasarkan wawancara pendahuluan terhadap beberapa karyawan, melakukan pekerjaan secara manual lebih kompleks dan membutuhkan waktu lama, sehingga mereka tidak dapat segera mengerjakan tugas-tugas lainnya. Sebagai contoh dalam melayani konsumen, ketika front officer melayani transaksi pembayaran secara manual, menimbulkan ketidaknyamanan konsumen karena menunggu lama. Penggunaan sisteminformasi ELTI secara optimal diharapkan dapat memudahkan pekerjaan karyawan mulai dari penyimpanan data siswa, transaksi pembayaran kursus, dan pembuatan jadwal teacher dan kelas. Kinerja karyawan yang efektif dan efisien pada akhirnya dapat meningkatkan kepuasan konsumen.

Peran sistem informasi manajemen adalah untuk mengelola data, pengorganisasian, dan mengambil informasi yang membantu organisasi untuk menyediakan layanan yang lebih cepat, lebih akurat dan lebih mudah, yang mempengaruhi juga pada tingkat kinerja (Gharaibeh dan Malkawi, 2013). Penggunaan system informasi ELTI yang belum optimal akan menghambat kinerja karyawan karena harus kembali melakukan pekerjaan secara manual yang membutuhkan waktu lama. Sebaliknya, efektivitas pemanfaatan system informasi ELTI yang optimal akan meningkatkan kinerja karyawan. Berdasarkan uraian di atas maka dapat dirumuskan pertanyaan penelitian yaitu "Bagaimanakah sistem informasi pada suatu perusahaan dapat meningkatkan kinerja karyawan?". Adapun tujuan dari penelitian ini adalah untuk mendeskripsikan efektivitas sistem informasi ELTI dalam meningkatkan kinerja karyawan. Hasil dari penelitian ini diharapkan dapat memberikan wawasan bagi pihak-pihak yang 
Efektivitas Sistem Informasi Dalam Meningkatkan Kinerja...

terkait dalam penggunaan sistem informasi di dalam perusahaan yang dapat meningkatkan kinerja karyawan.

\section{TELAAH PUSTAKA}

\section{Sistem Informasi Manajemen}

Raymond McLeod Jr (1995) mendefinisikan system informasi sebagai suatu system berbasis komputer yang menyediakan informasi bagi beberapa pemakai dengan kebutuhan serupa. Output informasi digunakan oleh manajer maupun non manajer dalam perusahaan untuk membuat keputusan dalam memecahkan masalah. Sistem informasi manajemen adalah serangkaian subsistem yang menyeluruh dan terpadu serta mampu mentransformasi data menjadi sebuah informasi untuk meningkatkan produktivitas sesuai dengan gaya dan sifattmanajer atas dasar kriteria mutu yang telah ditetapkan (Scott, M George, 2002)

Sistem informasi menurut Sutanto (2004), merupakan susunan dari orang-orang, kegiatan, data, jaringan (network) serta teknologi yang di integrasikan sedemikian rupa dengan tujuan untuk mendukung dan memperbaiki operasi sehari-hari perusahaan serta untuk memenuhi kebutuhan informasi baik untuk pengambilan keputusan maupun pemecahan masalah para manajer. Sehingga dapat disimpulkan bahwa pada hakikatnya, sistem informasi adalah seperangkat manusia, data dan prosedur yang bekerjasama secara terkoordinatif.

Menurut Yakub (2012) sistem adalah sekelompok elemen-elemen yang terintegrasi dengan tujuan yang sama untuk mencapai tujuan. Organisasi terdiri dari sejumlah sumber daya manusia, material, mesin, uang dan informasi. Sumber daya tersebut bekerja sama menuju tercapainya suatu tujuan tertentu yang ditentukan oleh pemilik atau manajemen.

Secara teori, computer tidak harus digunakan didalam SIM, tapi kenyataannya tidaklah mungkin SIM yang komplek dapat berfungsi tanpa melibatkan elemen komputer. SIM merupakan kumpulan sistemsistem informasi salah satunya adalah system informasi akuntansi yang menyediakan informasi dari transaksi keuangan.

Sistem informasi keuanganadalah sistem informasi yang dirancanguntuk menyediakan informasi mengenai arus uang bagi para pemakai di seluruh perusahaan. Secara umum sisteminformasi keuangan memiliki sistem pemasukan yang terdiri dari subsistem data processing didukung oleh internal audit subsistem yang menyediakan data daninformasi internal.

\section{Kualitas Sistem}

Kualitas sistem biasanya berfokus pada karakteristik kinerja sistem. Menurut DeLone dan McLean 1992 dalam Livari (2005) kualitas sistem merupakan ciri karakteristik kualitas yang diinginkan dari sitem informasi itu sendiri dan kualitas informasi yang diinginkan informasi terutama dalam bentuk laporan 
(reports). Kualitas informasi merupakan sejauh mana secara konsisten informasi dapat memenuhi persyaratan dan harapan semua orang yang membutuhkan informasit ersebutuntukmelakukan proses kegiatanmanusia. Indikator yang digunakan meliputi kemudahan untuk digunakan, kecepatan akses, keandalan sistem, fleksibilitas sistem dan keamanan sistem.

\section{Kinerja Karyawan}

Berkembangnya perusahaan merupakan keinginan dari setiap individu yang berada dalam perusahaan tersebut. Pembinaan dan pengembangan karyawan dalam perusahaan adalah salah satu kegiatan dalam rangka menyesuaikan diri dengan perubahan lingkungan. Oleh karena itu diperlukan penilaian atas pekerjaan yang telah dilaksanakan oleh karyawan perusahaan tersebut. Menurut Mangkunegara dalam Rivai (2009) kinerja adalah hasil kerja secara kuantitas dan kualitas yang dicapai oleh seorang pegawai dalam melaksanakan tugasnya sesuai tanggungjawab yang diberikan kepadanya.

\section{Penelitian Terdahulu}

Penelitian Vetendan Cameron (2002) yang berjudul "Empowerment and Devolution" yang menyatakan bahwa peningkatan kinerja berarti produktivitas yang lebih tinggi, kualitas yang lebih baik, pengurangan biaya, pengurangan kesalahan, kecepatan yang lebih tinggi dan kepuasan klien. Di sisi lain, TI meminimalkan kesalahan manusia dalam pengolahan informasi. Fakta-fakta ini menekankan bahwa TI mengarah pada kinerja karyawan yang lebih baik.

Menurut Rahadi (2007) dalam jurnalnya yang berjudul "Peranan Teknologi Informasi dalam Peningkatan Pelayanan di Sektor Publik" menjelaskan bahwa sistem informasi dan teknologi informasi sudah menjadi kebutuhan dasar bagi perusahaan, terutama dalam segala aspek aktivitas perusahaan. Penelitian tersebut dilakukan untuk mengetahui penggunaan TI terhadap penerimaan TI pada sektor pelayanan publik, dimana model yang dikembangkan menggunakan pendekatan model TAM yang dikemukakan Davis (1989). Lingkup masalah dalam penelitian ini dibatasi pada instansi Pemerintah yang memberikan pelayanan publik. Responden penelitian ini adalah 130 staf pegawai di lingkungan instansi Pemerintah yang memberikan pelayanan publik.

Menurut Model Ardalan, TI memainkan peran penting dalam pengumpulan data yang cepat, akses global dan cepat untuk berbagai informasi, evaluasi, komunikasi yang lebih baik melalui akseskeberbagaisumber informasi. Teknologi Informasi mengarahkekinerja yang lebihbaikdisertai dengan efisiensi yang lebih tinggi dalam pelayanan yang akan meningkatkan kepuasan layanan berkualitas tinggi dan cepat. Penelitian ini adalah review dari berbagai narasi. Literatur diperoleh dari database dan jurnal seperti Springer, Proquest dan PubMed.

\section{METODE PENELITIAN}


Efektivitas Sistem Informasi Dalam Meningkatkan Kinerja...

Penelitian ini merupakan penelitian kualitatif studi kasus karena tidak hanya mengetahui pengaruh sistem informasi manajemen terhadap kinerja, namun ingin menyelidiki dengan cermat dan mendalami seberapa efektif penggunaan sistem informasi dalam meningkatkan kinerja karyawan. Teknik pengumpulan data dengan melakukan wawancara mendalam terhadap 6 karyawan ELTI Gramedia Purwokerto yang terdiri Branch Manager, Academic, Front Officer, dan Accounting Staff yang secara langsung menggunakan sistem informasi ELTI dalam menjalankan tugas dan tanggung jawabnya. Penggunaan metode kualitatif sebagai prosedur penelitian menghasilkan data deskriptif berupa katakata baik tertulis maupun lisan dan perilaku orang - orang yang dapat diamati (Moleong, 2009).

\section{HASIL DAN PEMBAHASAN}

\section{Sistem Informasi ELTI Gramedia Purwokerto}

ELTI Gramedia memiliki sistem informasi yang digunakan oleh karyawan, baik oleh branch manager, front officer, accounting, maupun academic. Sebagian besar pekerjaan karyawan ELTI menggunakan sistem informasi yang memang dirancang untuk mempermudaqh karyawan dalam melakukan tugas dan tanggung jawabnya.. Sistem Informasi ELTI memiliki banyak kelebihan dan keunggulan, yaitu sederhana, mudah dioperasionalkan, respon cepat dan keamanan data terjamin.

Selain kemudahan dalam menjalankan sistem, respon dari sistem sangat cepat, tidak membutuhkan waktu lama untuk input data maupun jika ingin melihat data tertentu. Keamanan data terjaga karena tidak semua orang dapat mengakses sistem informasi tersebut. Hanya karyawan yang memiliki user name dan password yang dapat mengakses sistem tersebut. Sistem informasi ELTI sangat lengkap dan terintegrasi. Setiap karyawan memanfaatkan sistem informasi sesuai dengan bagiannya. Front officer hanya dapat mengakses data-data yang berhubungan pekerjaannya, begitu pula dengan accounting staff dan academic. Sistem Informasi ELTI yang dirancang sederhana dan fleksibel ini juga terkadang error di beberapa bagian, sehingga tidak dapat diakses. Namun demikian, pemulihan error tersebut tidak membutuhkan waktu lama, langsung diselesaikan jarak jauh oleh bagian IT dengan menggunakan aplikasi TeamViewer.

Secara keseluruhan, sistem informasi ELTI berkualitas baik. Sistem informasi ELTI sangat dibutuhkan oleh karyawan untuk menunjang pekerjaannya, karena hampir semua pekerjaan dilakukan dengan sistem. Pemanfaatan sistem ini sangat efektif dan efisien bagi karyawan ELTI Gramedia.

\section{Kinerja Karyawan ELTI Gramedia Purwokerto}

Penerapan Sistem informasi di ELTI Gramedia sangat menunjang pekerjaan karyawan. Sistem informasi ELTI digunakan hampir di semua bagian, seperti di bagian front office untuk input data siswa, mengecek jadwal teacher, membuat kwitansi pembayaran dan menyiapkan data-data untuk kelas dimulai. Bagian akademik menggunakan sistem informasi untuk membuat kelas baru, edit jadwal mengajar dan teacher, 
delay kelas, memasukkan nilai ujian dan membuat report siswa. Bagian keuangan menggunakan sistem informasi untuk mencatat pendapatan dan pengeluaran serta untuk menyusun laporan keuangan akhir bulan. Penyusunan laporan ini tidak dilakukan secara manual menggunakan microsoft excel, namun data-datanya tetap diambil dari sistem ELTI.

Informasi mengenai omset harian pun bisa diakses dari sistem, karena ketika siswa membayar, front officer akan membuat kwitansi pembayaran, yang akan terintegrasi langsung ke dalam report omset per hari. Khusus untuk bagian keuangan, memiliki sistem tersendiri selain sistem informasi ELTI yaitu BIBO (Bank In Bank Out). Sistem ini hanya dapat diakses oleh bagian keuangan saja. BIBO digunakan untuk input pendapatan dan pengeluaran selama satu bulan, dan akhirnya output dari bibo ini akan dilampirkan dalam laporan keuangan tiap bulan. Bagian keuangan wajib menyusun laporan setiap akhir bulan sebagai pertanggungjawaban kepada pimpinan dalam bentuk softcopy dan hardcopy.

Melakukan pekerjaan dengan sistem lebih mudah dan praktis dibandingkan dengan melakukannya dengan manual. Selain itu, menggunakan sistem informasi ELTI dalam bekerja dapat menghemat waktu karyawan, sehingga karyawan dapat melakukan pekerjaannya yang lain. Walaupun sistem informasi sangat membantu memperlancar pekerjaan karyawan, tidak menutup kemungkinan terdapat kendala atau hambatan yang dialami karyawan dalam melakukan pekerjaannya dengan sistem. Kendala tersebut bersifat teknis, contohnya koneksi internet kurang lancar, ada bagian dari sistem yang eror, adanya permasalahan di PC Komputer. Namun demikian, kendala - kendala tersebut dapat segera diatasi dengan log out dari sistem kemudian restart koneksi internet, setelah beberapa lama log in sistem kembali.

Pemanfaatan sistem informasi ELTI yang optimal akan meningkatkan kinerja karyawan. Semua pekerjaan yang menggunakan sistem dapat diselesaikan dengan cepat, efektif dan efisien dibandingkan dengan cara manual. Selain itu juga dapat menghemat waktu sehingga karyawan dapat segera melakukan pekerjaan yang lainnya. Produktivitas karyawan juga meningkat. Penelitian ini sesuai dengan teori dari Scott (2002) bahwa sistem informasi manajemen mampu mentransformasi data menjadi informasi guna meningkatkan produktivitas karyawan atas dasar kriteria mutu yang telah ditetapkan.

Hasil penelitian ini juga mendukung penelitian sebelumnya yang membuktikan bahwa terdapat hubungan kuat antara sistem informasi manajemen terhadap kinerja organisasi (Al Meetany et al, 2004 ; Gharaibeh dan Malkawi, 2013; Ajami dan Chadegani, 2014). Sistem informasi memudahkan pekerjaan manusia dan mengarah kepada kinerja yang lebih baik (Vetendan Cameron, 2002; DeLone dan McLeon 1992 dalam Livari, 2005). Kualitas sistem dan penggunaan sistem informasi yang efektif akan meningkatkan kinerja organisasi.

\section{PENUTUP}

\section{Kesimpulan}


Efektivitas Sistem Informasi Dalam Meningkatkan Kinerja...

Pemanfaatan sistem informasi secara efektif dapat meningkatkan kinerja karyawan. Kemudahan dalam mengoperasionalkan sistem membuat karyawan bekerja lebih cepat, efektif dan efisien. Walaupun masih terdapat hambatan, namun itu semua dapat diselesaikan dengan baik. Secara keseluruhan, penggunaan sistem informasi dalam bekerja meningkatkan produktivitas karyawan.

\section{Saran}

Saran untuk penelitian selanjutnya adalah menggunakan jenis perusahaan yang berbeda sebagai obyek penelitian dan mengeksplor tingkat kepuasan yang dirasakan pengguna sebuah sistem informasi sebagai indikator peningkatan kinerja karyawan dalam suatu organisasi.

\section{Keterbatasan Penelitian}

Penelitian ini memiliki keterbatasan yaitu dalam proses wawancara, peneliti merasa belum sepenuhnya menggali informasi karena ketersediaan informan dalam memberikan informasi sangat terbatas. Sehingga keinginan peneliti untuk mendalami dengan cermat seberapa efektif penggunaan sistem informasi dalam meningkatkan kinerja karyawan sesuai yang dirancang dalam metode penelitian, belum sepenuhnya terwujud.

\section{Daftar Pustaka}

Ajami, Sima; Chadegani, Raziyeh. 2014. The effects of applying information technology on job empowerment dimensions. Journal of Education and Health Promotion.

Ali, Wangdra. 2010. Technopreneurship dalam Perspektif Bisnis Online. Badoose Media. Jakarta

Al Meetany, Yousef Abdul Rahman Yousef. 2004. the impact of management information systems to improve the efficiency and effectiveness of the Jordanian Commercial Banks: A Case Study of Arab Bank, Master, Al al-Bait University. Faculty of Economics and Administrative Sciences. Jordan.

Fisher, B. and Kenny, R. 2000. Introducing a business information system into an engineering company. Journal of Information, Knowledge and Systems Management. Vol. 2, pp 207-221.

Gharaibeh, Shehadeh M.A.AL., Malkawi, Nazem M.M. 2013. The Impact of Management Information Systems on the Performance of Governmental Organizations- Study at Jordanian Ministry of Planning. International Journal of Business and Social Science. Vol. 4 No. 17.

Livari, J., 2005. An Empirical Test of the DeLone and McLean Model of Information System Success. Database for Advances in Information Systems. Vol. 36, No.2

Moleong, L. J. (2009). Metodologi Penelitian Kualitatif ed. Revisi. Bandung ; PT Remaja Rosdakarya.

Nugraha, Harmadhani Adi dan Astuti, Yuli Widi. 2013. Analisis Penerapan SistemInformasi Manajemen Keuangan Daerah (SIMDA Keuangan) dalamPengolahan Data Keuangan pada Organisasi Pemerintah Daerah (Studi Kasuspada Dinas Kesehatan Kabupaten Nganjuk). Jurnal Akuntansi Aktual. 2(1),25-33 
Rahadi, Dedi Rianto. 2007. ISSN: 1978-9777 :Peranan Teknologi Informasi dalam Peningkatan Pelayanan Sektor Publik. Yogyakarta.

Rivai, Veithzal. 2009. Manajemen Sumber Daya Manusia untuk Perusahaan: Dari Teori ke Praktek. Jakarta: PT Rajagrafindo Persada.

Scott, M George. 2002. Prinsip-Prinsip Sistem Informasi Manajemen. Jakarta : Raja grafindo Persada.

Sutanto, Azhar. 2004. Sistem Informasi Manajemen. Bandung: Lingga Jaya.

Veten, Diodie; Cameron, Kim S. 2002. Empowerment and Devolution. translated by Oure'ii Yazdi, Badredin, Tehran, Institute of Management research and Education.

Yakub. 2012. Pengantar Sistem Informasi. Yogyakarta: Graha Ilmu. 